\title{
KONSTRIBUSI KEBANGSAAN KIAI HASYIM ASY'ARI: Membangun Relasi Harmonis Islam dan Indonesia
}

\author{
Sholikah \\ Institut Agama Islam Nahdlatul Ulama Kab. Tuban \\ Email: sholihah@gmail.com \\ Nurotun Mumtahanah \\ Institut Agama Islam Al Hikmah Tuban \\ E-mail: ningmumun76@gmail.com
}

\begin{abstract}
Abstrak: Pemikiran tentang kalam sangat penting keberadaannya bagi semua kalangan, terutama bagi akademisi. Selain sebagai data sejarah, juga bisa dijadikan sumber pengetahuan sehingga bisa diaplikasikan untuk kehidupan saat ini dan mendatang. Salah satu pemikir kalam yang ada di Indonesia adalah KH. Hasyim Asy'ari. Penelitian ini penulis lakukan dengan pendekatan kualitatif, sumber informasinya diperoleh dari perpustakaan (library research). Penulis menemukan bahwa Kiai Hasyim adalah ulama karismatik dan putra terbaik bangsa. Pemikirannya tentang kalam dipengaruhi oleh kondisi sosio-historis saat beliau hidup. Di antaranya adanya berbagai ajaran pembaharuan dari para pembaharu untuk masyarakat Muslim Indonesia, selain itu juga kehadiran para penjajah. Dari kondisi tersebut beliau mendirikan pesantren dan organisasi NU. Bersama dua organisasi tersebut kiai Hasyim mengeluarkan fatwa jihad dan penghapusan tujuh kata kontroversial dalam Piagam Jakarta.
\end{abstract}

Kata kunci: KH. Hasyim Asy’ari, NU, Piagam Jakarta.

Abstract: Thinking about kalam is very important for all, especially academics. Aside from beig historical data, it can also be used as a source of knowledge, so it can be applied to current and future lives. One of the kalam thinkers in Indonesia is KH. Hasyim Asy'ari. This research is done by a qualitative approach, the source of information obtained from the library (library research). The autor faund that Hadratusy Syaikh Hasyim Asy'ari is a charismatic people and nation,s best son. His thinking about kalam was influenced socio-historical conditions when he lived. Among these are various reform teachings from reformers for the Indonesian Muslim Community, in addition to the presence of the invaders. From these conditions he established the pesantern and NU organizations. Together with the to organizations, kiai Hasyim issued a fatwa on jihad and the elimination of seven controversial word in the Piagam Jakarta.

Keywords: KH. Hasyim Asy'ari, NU, Piagam Jakarta.

\section{Pendahuluan}

Hadratusy Syaikh Hasyim Asy'ari merupakan salah satu ulama dan guru bangsa karismatik yang ada di Indonesia. Kehidupan kiai Hasyim didedikasikan untuk perjuangan dan pengabdian terhadap agama dan bangsa. Kiai Hasyim memiliki peran penting bagi bangsa Indonesia, selain merespon kondisi sosial politik dizamannya, beliau juga aktif bahkan ikut 
turun tangan dalam memperjuangkan bangsa Indonesia, sehingga tidak mengeherankan jika beliau dijadikan sebagai pahlawan nasional. Tak hanya itu, beliau juga mendirikan organisasi NU (Nahdlatul Ulama) yang saat ini terkenal di seluruh dunia dan memiliki banyak pengikut.

Perjuangan Kiai Hasyim Asy'ari untuk bangsa Indonesia sangatlah besar, beliau berani mempertaruhkan hidupnya demi kemerdekaan Indonesia dan mendeklarasikan fatwa jihad kebangsaan (resolusi jihad) untuk melawan penjajah. Dalam melawan pemerintahan Belanda, beliau memulainya dengan mendirikan pondok pesantren di Jombang dan mendirikan organisasi Nahdlatul Ulama. Selain itu, pemikirannya selalu dijadikan landasan dan panutan dalam memperjuangkan bangsa Indonesia. Salah satunya adalah semangat jihad yang selalu beliau kobarkan dalam rangka membebaskan Indonesia dari cengkraman penjajah. Berjihad dalam rangka membela kebenaran dan menegakkan keadilan adalah salah satu sikap yang selalu diperjuangkan oleh kiai Hasyim Asy’ari. ${ }^{1}$

\section{Sketsa Biografi KH. Hasyim Asy'ari}

Hadratusy Syaikh Hasyim Asy'ari dikenal dengan nama asli Muhammad Hasyim Asyari, lahir di Gedang pada hari selasa tanggal 24 Dzulqo'dah 1287 H / 14 Februari 1871. Ayahnya adalah pendiri pesantren Gedang pada akhir abad ke 19, sedangkan kakeknya adalah Kiai Shoihah yang merupakan pendiri pesantren Tambakberas, Jombang. ${ }^{2}$ Selain dikenal sebagai keturunan kiai, kiai Hasyim juga dikenal sebagai keturunan bangsawan, yaitu dari Raja Muslim Jawa. Sehingga silsilah Hadratusy Syaikh Hasyim Asy'ari adalah Muhammad Hasyim bin Asy'ari bin Abdurrahman bin Abdul Halim yang mendapatkan gelar Pangeran Benowo bin Abdurrahman yang mendapatkan gelar Jaka Tingkir Sulthan Hadi Wijaya bin Abdurrahman bin Abdul Aziz bin Abdul Fattah bin Maulana Ishaq bapaknya Raden Ainul Yaqin yang terkenal dengan nama Sunan Giri, Tebuireng, Jombang. ${ }^{3}$

Kiai Hasyim asy’ari wafat pada tanggal 7 Ramadhan 1366 H / 25 Juli 1947 di kediaman Pondok Pesantren Tebuireng, Jombang dan dimakamkan di dalam pondok yang telah dibangunnya. ${ }^{4}$

\section{Latar Belakang Pendidikan KH. Hasyim Asy'ari}

Sejak lahir hingga memasuki usia 15 tahun, kiai Hasyim dididik secara langsung oleh ayahnya. Pendidikan awalnya dimulai dengan belajar al-Qur'an dan berbagai kitab agama. Setelah usianya menginjak masa dewasa, kiai Hasyim berkelana untuk melanjutkan pendidikannya ke sejumlah Pondok Pesantren yang terkenal di pulau Jawa dan Madura, yakni di Pondok Pesantren Wonokoyo (Probolinggo), Pondok Pesantren Siwalan Panji (Sidoarjo), Pesantren Langitan (Tuban), Pesantren Kademangan (Bangkalan, Madura), selain itu beliau pernah juga berguru kepada kiai Saleh Darat bin Umar (Semarang). ${ }^{5}$

Setelah mendapat bekal pendidikan dari berbagai pesantren, kiai Hasyim melanjutkan pendidikannya ke Makkah al-Mukarramah dan beberapa tempat terkenal di tanah haram

\footnotetext{
${ }^{1}$ Saifuddin Zuhri, Berangkat dari Pesantren (Yogyakarta: LKiS, 2013), 470.

${ }^{2}$ Lathifatul Khuluq, Fajar Kebangunan Ulama: Biografi KH. Hasyim Asy'ari (Yogyakarta: LkIS, 2000), 17.

${ }^{3}$ Lathifatul Khuluq, Fajar Kebangunan Ulama..., 15.

${ }^{4} J a m a l$ Ma'mur Asmani, Pemikiran Kiai Hasyim Asy'ari: tentang Agama, Perempuan, dan Kemasyarakatan (Yogyakarta: Aswaja Pressindo, 2018), xiv.

${ }^{5}$ Khasanah dan Waskito, "Genealogi Pemikiran Pendidikan KH. Hasyim Asy'ari”, Analisa: Jurnal Studi Keislaman, 2019, 24. http://doi.org/10.24042/ajsk.v19il.3397
} 
tersebut selama beberapa tahun. Kiai Hasyim belajar kepada ulama-ulama besar seperti Syekh Muhammad Nawawi al-Bantani, Syekh Khotib al-Minangkabawi, Syekh Syu'aib bin Abdurrahman yang memiliki kemampuan dalam berbagai cabang ilmu pengetahuan, kemudian belajar kitab-kitab hadits kepada Sayyid Abbas al-Maliki al-Hasani. Selain itu juga belajar ilmu-ilmu Syari'at, sastra, dan gerakan-gerakan modern kepada Syekh Muhammad Mahfudh bin Abdurrahman al-Tarmasi yang merupakan ulama ahli hadis di Mekah. Saat kiai Hasyim belajar di Mekah, Muhammad Abduh sedang giat-giatnya melancarkan gerakan pembaharuan pemikiran Islam. Sebagaimana diketahui bahwa buah pikiran Abduh mampu mempengaruhi perjalanan umat Islam selanjutnya. Deliar Noer mengungkapkan bahwa ideide reformasi Islam yang dianjurkan oleh Abduh yang dilancarkan di Mesir telah menarik perhatian santri-santri Indonesia yang sedang belajar di Mekah. ${ }^{6}$ Ide reformasi Abduh meliputi: Pertama, mengajak umat Islam untuk memurnikan kembali Islam dari pengaruh dan praktik keagamaan yang sebenarnya bukan berasal dari Islam. Kedua, reformasi pendidikan Islam di tingkat universitas. Ketiga, mengkaji dan merumuskan kembali doktrin Islam untuk disesuaikan kebutuhan hidup modern. Alasan inilah yang melancarkan ide Abduh agar umat Islam melepaskan diri dari keterikatan mereka kepada pola pikir para mazhab dan supaya umat Islam meninggalkan segala bentuk praktik tarekat. ${ }^{7}$ Kiai Hasyim sebenarnya menerima beberapa ide Abduh untuk menyemangatkan kembali Islam, namun Kiai Hasyim menolak poin yang menyarankan agar umat Islam melepaskan diri dari keterikatan mazhab.

Kyai Hasyim juga tidak terpengaruh dengan doktrin Wahabi yang dikenal sebagai puritan dan menolak berbagai tradisi kaum tradisionalis (lokal). Bahkan beliau menolak doktrin Wahabi tersebut dan memberikan penjelasan yang elaboratif, terkhusus dalam memahami heterodoksi dalam agama (bid'ah). Setelah kiai Hasyim menguasai berbagai ilmu, beliau kembali ke Indonesia dan meneruskan kegiatan mengajar santri, mengarang kitab, dan mendirikan Pondok Pesantren Tebuireng Jombang pada tahun 26 Rabi'ul Awwal 1317. Kemudian disusul dengan membangun Madrasah Salafiyyah Syafi'iyyah, dan memimpin proses pengajarannya. ${ }^{8}$ Selain itu, kiai Hasyim juga mendirikan organisasi atau jam'iyyah yang dijadikan wadah untuk diskusi dan membahas permasalahan sosial-keagamaan kaum Muslim. Kemudian pada tanggal 31 Januari 1926, kiai Hasyim bersama dengan muridnya KH. Wahab Hasbullah dan beberapa ulama lainnya mendeklarasikan berdirinya organisasi Nahdlatul Ulama (NU). ${ }^{9}$

Oraganisasi NU merupakan organisasi sosial keagamaan, didirikan untuk membela umat Islam tradisionalis supaya mereka tetap berpegang pada al-Qur'an, Hadits, menghindari kesesatan dan bid'ah, serta antusias berjuang dalam menegakkan keagungan kalimat Allah. ${ }^{10}$ Didirikannya organisasi NU juga ditujukan untuk melawan segala bentuk penjajahan dan merebut kemerdekaan Negara Kesatuan Republik Indonesia dari penjajahan Belanda dan Jepang, sekaligus sebagai organisasi yang aktif berdakwah untuk menjaga kesatuan bangsa Indonesia dalam wadah NKRI. Motif nasionalisme timbul karena NU lahir dengan niat kuat

\footnotetext{
${ }^{6}$ Deliar Noer, Gerakan Islam di Indonesia 1900-1942 (Jakarta: LP3ES, 1996), 130.

${ }^{7}$ Syamsun Ni'am, Wasiat Tarekat Hadratus Syaikh Hasyim Asy'ari (Jogjakarta: Ar-Ruzz Media, 2011), 99.

${ }^{8}$ Jamal Ma'mur Asmani, Pemikiran Kiai Hasyim Asy'ari...., xii.

${ }^{9}$ Robin Bush dan Greg Fealy, "The Political Decline of Traditional Ulama in Indonesia", Asian Journal of Social Science, Vol. 42, No. 5, 2014, 94. https://doi.org/10.1163/15685314-04205004

${ }^{10}$ Robin Bush dan Greg Fealy, ...., 55. https://doi.org/10.1163/15685314-04205004
} 
untuk menyatukan para ulama dan tokoh-tokoh agama dalam melawan penjajah. ${ }^{11}$ Itulah sebabnya organisasi yang didirikan kiai Hasyim dinamakan Nahdlatul Ulama "Kebangkitan Para Ulama", bukan dengan nama Nahdlatul Muslimin ataupun Nahdlatul Ummah. ${ }^{12}$ Pondok Pesantren Tebuireng dan organisasi Nahdlatul Ulama keduanya adalah peninggalan besar dari beberapa karya terbaik kiai Hasyim.

Kiai Hasyim Asy'ari selain menjadi ulama yang karismatik, juga merupakan guru bangsa. Potensi yang dimiliki kiai Hasyim dalam memimpin umat Islam menjadi beliau memiliki peran penting dalam memajukan masyaraktnya dan membangkitkan semangat perjuangan, baik dalam bidang kemanusiaan, keagamaan ataupun kebangsaan. Hal ini terlihat dari banyaknya santri yang ikut berjuang dalam rangka membebaskan bangsa Indonesia dari penjajahan. ${ }^{13}$

\section{Karya Intelektual KH Hasyim Asy'ari}

Hadratusy Syaikh Hasyim Asy'ari adalah salah satu ulama yang sangat produktif dalam merespon kondisi sosial-politik di Indonesia, hal ini dapat dibuktikan dengan adanya beberapa karya beliau, meliputi:

a. Adabul Alim wa al-Muta'allim, merupakan kitab yang menjelaskan tentang segala sesuatu yang dibutuhkan oleh pelajar dan pengajar ditengah proses belajarmengajarnya.

b. Al-Tanbihat al-Wajibat, liman Yashna'u al-Maulida bi al-Munkarat, berisi tentang nasihat penting bagi orang yang merayakan Nabi Muhammad dengan menjalankan hal-hal yang dilarang oleh agama.

c. Qanun al-Asasi li Jam'iyyah an-Nahdat al-Ulama', berisi tentang beberapa aturan dasar organisasi Nahdlatul Ulama.

d. Al-Risalah al-Jami'ah, berisi penjelasan tentang keadaan orang-orang yang meninggal, tanda-tanda hari kiamat, juga tentang Sunnah dan bid'ah.

e. Al-Nurul Mubin fi Mahabbati Sayyidil Mursalin, menjelaskan tentang pengertian kepada Rasulullah Saw. dan hal-hal yang berhubungan dengan para pengikut dan bagaimana menghidupkan budayanya.

f. Hasyiyah ala Fathirrahman bi Syarhi Risalah al-Wali Ruslam li Syekh Islam Zakariyya al-Anshari.

g. Ziyadat al-Ta'liqat ala Manzumat as-Syaikh 'Abd Allah bin Yasin al-Fasuruani, menjelaskan tentang bantahan kiai Hasyim terhadap kritikan Syaikh Abdullah bin Yasin Pasuruan terhadap Nahdlatul Ulama.

h. Al-Durar al-Muntasirah fi al-Masail al-Tis'a 'Asyarah, menjelaskan tentang tariqat, kewaliyan dan hal-hal yang berhubungan dengan masalah-masalah penting bagi ahli tariqat.

i. Al-Tibyan fi al-Nahyi an Muqotha'ati al-Ikhwan, berisi penjelasan tentang pentingnya silaturrahim dan bahayanya bagi yang memutuskan.

\footnotetext{
${ }^{11}$ Mohammad Rizal Fadli dan Hidayat, KH. Hasyim Asy'ari dan Resolusi Jihad dalam Usaha Mempertahankan Kemerdekaan Indonesia Tahun 1945, (Lampung: Laduny Alifatama, 2018), 12.

${ }^{12}$ Ahmad Khoirul Anam, dkk. Ensiklopedia Nahdlatul Ulama: Sejarah, Tokoh, dan Khazanah Pesantren Jilid 2 , (Jakarta: Pustaka Kompas, 2014).

${ }^{13}$ Lathifatul Khuluq, Fajar Kebangunan Ulama..., 90.
} 
j. Al-Risalah al-Tauhidiyyah, merupakan kitab yang menjelaskan tentang akidah Ahlus Sunnah wa al-Jama'ah (dalam bidang teologi).

k. Al-Qolaid fi Bayani ma Yajibu min al-Aqo’id, berisi kumpulan empat puluh hadis Nabi. $^{14}$

\section{Corak Pemikiran Islam dan Jejak Patriotisme KH. Hasyim Asy'ari}

\section{Konstruk Paham Keagamaan KH Hasyim Asy'ari}

Beberapa pemikiran kiai Hasyim Asy’ari tidak bisa dipisahkan dari latar belakang sosio-historis yang melingkupinya. Pemikirannya menggambarkan tentang keseriusannya dalam menahan laju ekspansi gerakan purifikasi agama dan modernisme di Nusantara, terkhusus daerah Jawa, serta keadaan sosial masyarakat yang masih berjuang untuk lepas dari penjajahan kolonialisme. ${ }^{15}$ Kiai Hasyim berpendapat bahwa keberadaan Islam sesungguhnya bukan hanya sebagai pembebas dan pembimbing bagi manusia yang menyembah lebih dari satu Tuhan (politeisme), melainkan juga sebagai upaya untuk memajukan aspek sosial, politik, masyarakat yang masih terbelakang, dan berusaha memupuk persaudaraan dengan menghilangkan perbedaan yang disebabkan oleh faktor nasab, kekayaan dan kebangsaan. ${ }^{16}$

Keseriusan kiai Hasyim dalam merespon permasalahan sosial terlihat dari jawabannya yang bersifat membela sekaligus mengkritik kelompok yang ada ketika itu. Terbukti dari pembelaan kiai Hasyim terhadap beberapa kritikan yang dilontarkan kaum puritan kepada kaum tradisionalis, yakni tentang ziarah kubur, keyakinan akan adanya syafa'at, tawassul, dan lain sebagainya. Tidak hanya membela saja, kiai Hasyim sendiri juga memberikan kritiknya kepada kaum tradisionalis. Kiai Hasyim mengkritik terhadap ritual ibadah-ibadah di kalangan Muslim Jawa yang justru terkesan telah menyimpang dan tidak sesuai dengan substansinya, misalnya dalam memperingati Maulid Nabi dan praktek bertarekat yang berlangsung di kalangan masyarakat Muslim Jawa. Maulid Nabi menurut kiai Hasyim penting untuk dilakukan, karena mampu membangkitkan rasa cinta kepada Nabi Muhammad Saw. Melalui maulid Nabi, setiap orang akan mengingat serta meluhurkan Nabi. Maulid Nabi juga sebagai manifestasi syukur kepada Allah Swt. atas diutusnya Nabi Muhammad Saw. sebagai Rasul bagi seluruh alam semesta. Namun masyarakat saat itu mulai menjauh dari tujuan utama diadakannya peringatan Maulid Nabi, yaitu menjadikan maulid Nabi sebagai ajang kemungkaran, hal tersebut yang justru telah menggeser peringatan yang mulia menjadi haram. ${ }^{17}$

Kritik kiai Hasyim terhadap kaum tradisionalis selanjutnya adalah praktek-tarekat di Jawa, terutama praktek tarekat yang tidak mengacu pada syariat. Praktek tarekat yang tumbuh di Jawa harus tetap dilestarikan sebagai bentuk tradisi Islam. Upaya pelestarian tarekat hanya dapat dilakukan dengan tidak melanggar ketentuan syariat. Menurut kiai Hasyim, sebagian praktek tarekat Jawa telah terjadi penyelewengan bahkan menyimpang. Penyelewengan terjadi pada fenomena tarekat yang dalam prakteknya terlalu banyak memberikan otoritas kepada guru tarekat melebihi proporsi yang lazimnya diberikan pada wali. Pemberian otoritas

\footnotetext{
14 Jamal Ma'mur Asmani, Pemikiran Kiai Hasyim Asy'ari..., xv.

15 Achmad Muhibbin Zuhri, Pemikiran KH. M. Hasyim Asy'ari: tentang Ahl as-Sunnah wa al-Jama'ah (Surabaya: Khalista, 2010), 204.

${ }^{16}$ Lathifatul Khuluq, Fajar Kebangunan Ulama, 57.

${ }^{17}$ Achmad Muhibbin Zuhri, Pemikiran KH. M. Hasyim Asy'ari, 193.
} 
yang berlebihan sangat berbahaya karena akan melahirkan pengkultusan individu yang bertentangan dengan syariat Islam. ${ }^{18}$ Selain itu, kiai Hasyim mengkritik atas klaim mursyid yang dianggap wali sehingga dijadikan alasan untuk mengabaikan syariat. Kiai Hasyim mengakui adanya mursyid, hanya saja mursyid yang telah menempati derajat kewalian tidak seharusnya meninggalkan syariat. Kiai Hasyim menganjurkan umat Islam untuk menjauhi wali sesat dan pratek tarekat yang menyimpang.

Selain itu, Muslim Jawa juga mulai mengikuti dan melestarikan pemikiran Muhammad Abduh, Rasyid Ridha, Muhammad bin Abdul Wahhab an-Najdi, Ibn Qayyim alJauziyyah. Pemikiran Muhammad bin Abdul Wahab atau dikenal dengan kaum Wahabi yang mengharamkan semua apa yang dilakukan oleh kelompok pertama. Menurutnya, tauhid kelompok tradisionalis sudah tidak lagi murni, karena sudah bercampur dengan tahayyul, bid'ah, dan khurafat. Setelah kaum Wahabi, para modernis juga ingin mendorong kaum tradisionalis untuk tidak berlaku taqlid, karena pintu ijtihad masih terbuka lebar. Demi terwujudnya cita-cita modernisme, pengikut kelompok ini melakukan gagasan pembaharuan melalui media cetak, dengan menerbitkan buku, jurnal dan majalah, mendirikan madrasah dan membentuk organisasi sosial dan keagamaan. ${ }^{19}$

Respon kiai Hasyim untuk kelompok kedua diarahkan pada tuduhan kaum Wahabi tentang ritual masyarakat Jawa mengenai tahlil, ziarah kubur, dan tawassul yang dianggap bid'ah, sehingga pelakunya tergolong orang yang musyrik. Menanggapi hal tersebut, kiai Hasyim dengan tegas menyatakan bahwa tidak ada alasan untuk melarang ziarah kubur, termasuk di dalamnya mengunjungi makam Nabi. Ziarah kubur menjadi penting bagi umat Islam, sehingga tidak masuk ke ranah bid'ah. Kiai Hasyim menyatakan bahwa barangsiapa yang tidak mengakui status sunnah dalam praktek ziarah ke makam Nabi, maka hal itu termasuk perbuatan yang menentang Allah, Nabi Muhammad, dan kesepakatan para ulama. Demikian juga dengan persoalan tahlil dan tawassul kepada Nabi dan orang-orang sholih. Kiai Hasyim menyatakan bahwa tidak ada larangan sedikitpun tentang praktek tawassul. Bertawassul melalui Nabi dan orang-orang sholih adalah diperbolehkan, baik kepada orang sholih yang masih hidup ataupun yang sudah meninggal. ${ }^{20}$ Bagi kiai Hasyim, sesungguhnya orang yang sedang bertawassul itu tengah berdoa kepada Allah, hanya saja demi terkabulnya doa dibutuhkan pertolongan orang yang telah ditetapkan memiliki derajat yang luhur di sisi Allah, seperti halnya para Nabi, para wali, dan orang-orang sholih. Kiai Hasyim mengatakan:

"Permintaan kepada Allah (melalui tawassul, tahlil, dan meminta syafaat) dalam doadoa yang dipanjatkan seluruhnya dirujukan kepada Allah dengan kesendirian-Nya dan tiada sekutu bagi-Nya namun menggunakan berbagai macam perantara, hal itu tidak ditetapkan sebagai syirik atau meminta kepada selain-Nya, dan begitu pula meminta kepada Muhammad Saw, dan wali yang sholih, bukan berarti meminta kepada mereka akan tetapi justru meminta kepada Allah Swt dengan ke Esaannya melalui mereka, tawassul, tahlil, dan tasaffu' melalui

\footnotetext{
${ }^{18}$ Ibid., 195.

${ }^{19}$ Merle Calvin Ricklefs, Mengislamkan Jawa: Sejarah Islamisasi di Jawa dan Penentangnya dari 1930 sampai Sekarang (Jakarta: Serambi Ilmu Pustaka, 2012), 30.

${ }^{20}$ Miftahuddin, "Dari Pesantren Untuk Negeri: Kiprah Kebangsaan KH. Hasyim Asy’ari”, Jurnal Islam Nusantara, Vol. 03, No. 02, 2019, 318.
} 
berbagai macam cara, bukan berarti di dalam hati umat Islam meminta kepada selain Allah dan bermaksud kepada selain mereka selain Allah Swt."21

Selain itu, kiai Hasyim juga mengkritik kaum Wahabi yang mengaku sebagai penerus Ibn Taimiyyah yang menuduh tawassul, istighasah, dan tasyaffu' sebagai praktik keagamaan bid'ah dan syirik. Menurut kiai Hasyim, kaum modernis telah melakukan kebohongan karena Ibn Taimiyyah telah mengakui keabsahan tawassul, istighasah, dan tasyaffu'. ${ }^{22}$ Seperti halnya kaum Wahabi, pandangan para modernis juga mendapatkan respon dari kiai Hasyim. Menurut kiai Hasyim, taqlid diperbolehkan bagi orang yang tidak memiliki kemampuan untuk memahami, adapun larangan taqlid hanya berlaku bagi orang-orang yang mampu untuk berijtihad. Kiai Hasyim menegaskan dalam kitab Qanun al-Asasi Nahdat al-Ulama' bahwa larangan taqlid hanya ditujukan kepada mereka yang mampu dalam melakukan ijtihad meskipun kemampuan yang dimiliki hanya dalam satu bidang, dan bagi para Mujtahid dilarang bertaqlid pada hasil ijtihad orang lain. ${ }^{23}$ Alasan yang diberikan kiai Hasyim atas diperbolehkannya taqlid karena tidak semua orang memiliki keahlian dalam berijtihad, oleh karenanya orang yang tidak memiliki kemampuan diwajibkan atasnya untuk mengikuti pendapat Salaf as-Shalih. Taqlid menjadi sesuatu yang sangat penting, karena tidak mudah untuk memahami teks-teks keagamaan. ${ }^{24}$

Selanjutnya, pemikiran kiai Hasyim tentang ketauhidan banyak disandarkan pada pendapat ulama pertengahan, seperti yang terlihat dalam karyanya yang berjudul al-Risalah al-Tauhidiyyah dan al-Qaid fi Bayan Ma Yajib Min al-Qaid, dalam kitab ini kiai Hasyim banyak mengutip pendapat Imam Qusyairi yang menjelaskan bahwa ada tiga tingkat apresiasi manusia tentang Tuhan. Pertama, penilaian tentang keesaan Tuhan, yang merupakan pemahaman tauhid untuk orang awam. Kedua, pengetahuan dan teori kepastian adalah bersumber dari Allah, merupakan pemahaman tauhid untuk para ulama. Ketiga, menggambarkan dari perasaan yang paling dalam akan keagungan Tuhan, merupakan pemahaman para sufi yang membawa kepada pengetahuan tentang Tuhan (ma'rifat). ${ }^{25}$ Adapun hakikat dari iman meliputi rukun iman, yaitu percaya kepada Allah Swt, Malaikatmalaikat Allah, Kitab-kitab Allah, Nabi-nabi Allah, serta percaya akan hari akhir yang telah ditetapkan oleh Allah. ${ }^{26}$

\section{Peran Kepahlawanan KH Hasyim Asy'ari}

KH. Hasyim Asy'ari merupakan tokoh yang menyadari betul apa tugas manusia di bumi ini, sebagai khalifah Allah sudah seharusnya selalu berjuang dalam hal kebaikan. Sebagaimana dalam Surat al-Baqarah ayat 30 yang menjelaskan bahwa menjadi khalifah Allah berarti selalu menebar kebaikan dan menutup potensi keburukan, karena hakikat dari khalifah adalah wakil Allah di bumi. Menurut kiai Hasyim, menjadi seorang khalifah berarti

${ }^{21}$ KH. M. Hasyim Asy'ari, Cahaya Purnama Kekasih Tuhan, terj. Nur al-Mubin fi Mahabbat as-Sayyid alMursalin (Tebuireng: Pustaka Tebuireng), 74.

${ }^{22}$ Ibid.,82.

${ }^{23}$ Muchamad Coirun Nizar, "Pemikiran KH. Hasyim Asy’ari tentang Persatuan”, Endogami: Jurnal Ilmiah Kajian Antropologi, 2017. http://www.DOI:10.14710/endogami.1.1.63-74

${ }^{24}$ Tim Dosen Ma'had Aly Hasyim Asy'ari, Cahaya Penerang Jiwa, terj. Risalah Ahl-as-Sunnah wa al-Jama'ah, (Tebuireng: Pustaka Tebuireng), 16.

${ }^{25}$ Latifatul Khuluq, Hasyim Asy'ari: Religous Thought and Polirical Activities (1871-1947) (Jakarta: Logos), 48.

${ }^{26}$ KH. M. Hasyim Asy'ari, Ar-Risalat al-Jami'at al-Maqasid (Jombang: Pustaka Warisan Islam Tebuireng, tt), 4. 
sepenuh hati merepresentasikan nilai-nilai ketuhanan. Khalifah sejati adalah orang yang selalu berpikir apa yang telah ia perbuat untuk sesama, bangsa dan negaranya. Dalam hal ini kiai Hasyim Asy'ari berpijak pada hadis Nabi yang mengatakan bahwa sebaik-baiknya manusia adalah yang paling bermanfaat bagi sesamanya. Prinsip hidup kiai Hasyim ini terbukti mampu mempengaruhi beberapa ulama dan pahlawan dari Jombang, kesemuanya terbukti telah mengabdikan hidupnya untuk bangsa dan negara. Kiai Hasyim berprinsip bahwa melawan berbagai bentuk kedhaliman adalah harga mati yang tak bisa ditawar lagi. Bagi beliau bahwa wafat di jalan kebenaran adalah syahid, sedangkan yang lari dari medan peperangan adalah bentuk dari penghianatan. ${ }^{27}$

KH. Hasyim Asy'ari adalah pendiri organisasi (jam'iyyah) Nahdlatul Ulama yang memiliki spirit perjuangan dan tanggung jawab yang sangat tinggi. Beliau sangat berjasa dalam memerdekakan Indonesia. Bagi kiai Hasyim, kemerdekaan adalah syarat mutlak dalam membumikan kesejahteraan dan keadilan sosial. Demi mencapai kemerdekaan tersebut, beliau sangat anti terhadap segala bentuk kerjasama pada penjajah. Terbukti bahwa beliau pernah menolak penghargaan sebagai tanda kehormatan yang akan diberikan pemerintah kolonial Belanda kepada kiai Hasyim. ${ }^{28}$ Kiai Hasyim selalu menjadikan Surat al-Baqarah ayat 30 tersebut sebagai landasan untuk tidak akan bekerja sama dengan para penjajah.

Kiai Hasyim selalu mengingatkan akan pentingnya persatuan dan kesatuan umat supaya sebuah perjuangan akan membuahkan hasil yang baik. Persatuan dan kesatuan umat sangat penting dalam menghadapi Belanda yang menggunakan taktik pecah belah, karena dengan perpecahan itulah masyarakat Nusantara akan mudah dijajah oleh pihak asing. Persatuan yang dimaksudkan kiai Hasyim bukan hanya persatuan fisik, melainkan juga persatuan hati yang diharapkan mampu melahirkan kesatuan idealisme dan cita-cita bersama, sehingga imperialisme penjajah dapat dengan mudah diatasi. ${ }^{29}$ Kesadaran untuk bersatu itulah yang kemudian menjadi sebuah momentum dalam membangun semangat perjuangan rakyat Indonesia. Bagi masyarakat Indonesia yang sedang berjuang, beliau mengeluarkan fatwa mengharamkan umat Muslim untuk menjadi tentara penjajah ataupun menjalin kerja sama dalam bentuk apapun. Fatwa tersebut ternyata cukup efektif untuk menyadarkan masyarakat supaya selalu bersatu dalam memerangi penjajah. Nasionalisme dalam kacamata kiai Hasyim bukan hanya sebuah istilah, namun merupakan manifestasi konkrit dan kecintaan seseorang pada tanah airnya, yang harus dibuktikan dengan sebuah pengorbanan. Hal inilah yang menjadikan beliau sebagai pahlawan nasional, kiai Hasyim memang lahir di Jombang, namun seluruh hidupnya didedikasikan untuk bangsa dan negara Indonesia. ${ }^{30}$

Pemikiran kiai Hasyim tentang kebangsaan sangat berpengaruh bagi Indonesia, baik saat Indonesia masih terjajah ataupun setelah merdeka. Kiai Hasyim Asy'ari merupakan tokoh yang sangat cerdas dan berpengaruh. Penderitaan yang dialami bangsa Indonesia dan pengekangan terhadap kebebasan dalam menjalankan perintah agama, menjadikan kiai Hasyim terdorong untuk mengeluarkan fatwa tentang jihad melawan Belanda. Sejarah mencatat jihad yang dideklarasikan kiai Hasyim sebagai jihad kebangsaan. Sebagai ulama

\footnotetext{
${ }^{27}$ Rozikin Daman, Membidik NU: Dilema Percaturan Politik NU Pasca-Khittah (Yogyakarta: Gama Media, 2001), 104.

${ }^{28}$ Saifuddin Zuhri, Berangkat dari Pesantren, 169.

${ }^{29}$ Muchamad Coirun Nizar, "Pemikiran KH. Hasyim Asy’ari tentang Persatuan", 66.

${ }^{30}$ Latifatul Khuluq, Fajar Kebangunan Ulama, 127.
} 
karismatik yang menjadi panutan, kiai Hasyim menggelorakan semangat kepada anak muda dan para santri untuk berjihad melawan penjajahan serta menolak berbagai bentuk kerjasama dengan Belanda. Jihad kebangsaan yang dideklarasikan oleh kiai Hasyim terbukti sangat efektif dalam membakar patriotisme umat, sehingga para penjajah bisa dilenyapkan dari bumi pertiwi ini. Jihad menjadi ikatan solidaritas (persatuan) yang mampu mengetuk setiap hati kaum Muslim untuk melakukan perlawanan kepada pemerintahan Belanda. ${ }^{31}$

Kiai Hasyim dianggap sebagai provokator yang cukup berbahaya dalam perjuangan kemerdekaan NKRI. Sehingga tidak mengherankan jika seluruh aktivitas yang dilakukan kiai Hasyim selalu berada dalam pengawasan Belanda. Meski demikian, kiai Hasyim tetap semangat dalam menjalankan segala aktivitas sosial keagamaannya. Bahkan kiai Hasyim masih terus memberikan semangat dan motivasi kepada rakyat Indonesia untuk terus berjuang sampai tetes darah penghabisan. ${ }^{32}$

Kiprah kebangsaan kiai Hasyim dalam melawan penjajahan Belanda menjadi sangat urgen ketika beliau mendeklarasikan fatwa jihad dengan mengumpulkan para ulama dan kiai NU dari berbagai wilayah (terkhusus Jawa dan Madura) pada tanggal 21-22 Oktober 1945 di Surabaya. Tujuan dari perkumpulan tersebut adalah untuk mengukuhkan jihad dalam melawan penjajah, dalam forum tersebut memutuskan bahwa jihad melawan penjajah dihukumi sebagai perang suci (jihad fi sabilillah). Menurut kiai Hasyim, membela tanah air dan bangsa adalah wujud nasionalisme dan kecintaannya pada agama. Dengan demikian, membela tanah air adalah bukti kecintaan terhadap agama merupakan mainstream yang dibangun kiai Hasyim untuk membangkitkan semangat perlawanan terhadap para penjajah. Selain itu, kiai Hasyim berpandangan bahwa orang yang berjihad di jalan Allah akan mendapatkan pahala yang berlipat-lipat di akhirat kelak. Banyak para pemuda yang responsif atas fatwa tersebut, sehingga mereka dengan suka rela bergabung dengan barisan para pejuang. Adapun isi fatwa jihad yang dikukuhkan sebagai resolusi jihad yaitu:

a) Kemerdekaan Indonesia yang diproklamasikan tanggal 17 Agustus 1945 wajib untuk dipertahankan,

b) Republik Indonesia adalah satu-satunya pemerintahan yang sah, karenanya wajib dibela dan diselamatkan,

c) Musuh Republik Indonesia terutama Belanda yang datang dengan membonceng tugas tentara Sekutu (Inggris) dalam masalah tawanan perang bangsa Jepang tentu akan menggunakan kesempatan politik dan militer untuk kembali menjajah Indonesia,

d) Umat Islam terutama NU wajib mengangkat senjata untuk melawan Belanda dan sekutunya yang hendak kembali menjajah Indonesia,

e) Jihad adalah kewajiban (fardlu 'ain) bagi setiap orang Islam yang berada pada jarak radius $94 \mathrm{~km}$.

Resolusi jihad ini yang kemudian dijadikan resolusi umat Islam di Yogyakarta. Bahkan resolusi ini dijadikan salah satu sumber yang memberikan motivasi kuat pada ribuan umat Muslim yang tergabung dalam laskar-laskar rakyat yang sangat aktif melibatkan diri dalam pertempuran 10 November di Surabaya, Palagan Ambarawa, pertempuran Semarang, Bandung Lautan Api, dan berbagai pertempuran lainnya. Pada bulan Oktober 1945 dan beberapa bulan berikutnya, berbagai surat kabar Kedaulatan Rakyat sering muncul dan

\footnotetext{
${ }^{31}$ Chusnul Chotimah, “Aktualisasi Pemikiran KH. M. Hasyim Asy’ari tentang Kenegaraan dan Kebangsaan”, Jurnal Inovatif, Vol. 3, No. 2, 2018, 128.

${ }^{32}$ Miftahuddin, “Dari Pesantren Untuk Negeri: Kiprah Kebangsaan KH. Hasyim Asy’ari”, ......320.
} 
memuat berita-berita heroik dari barisan kiai dan laskar rakyat bersama kekuatan nasional lainnya. ${ }^{33}$ Resolusi jihad yang difatwakan oleh kiai Hasyim memiliki dampak yang luar biasa bagi kehidupan bangsa dan negara, pertama, dalam bidang politik. Ruh dan semangat resolusi jihad meneguhkan kedaulatan Indonesia sebagai bangsa yang merdeka dari segala bentuk penjajahan. Bangsa Indonesia berdarah-darah dalam memperjuangkan kemerdekaannya dari tentara sekutu. Kedua, dalam bidang militer. Adanya resolusi jihad memunculkan berbagai laskar pejuang, seperti Laskar Hisbullah, Sabilillah, TKR dan sebagainya yang berkontribusi bagi kemunculan tentara nasional. Tanpa adanya laskar-laskar yang terkomando oleh resolusi jihad, maka usaha rekruitmen tentara nasional akan mengalami kesulitan. ${ }^{34}$

Bukan hanya Belanda yang menjadi sasaran kiai Hasyim, tetapi juga Jepang yang ikut berkuasa di Indonesia. Begitu rakyat Indonesia mampu mengusir Belanda dari wilayah Jawa, Jepang datang dengan beberapa kebijakannya. Kiai Hasyim merupakan salah satu penentang kebijakan yang telah dibuat Jepang secara sepihak, beliau menolak untuk melakukan seikerei. ${ }^{35}$ Akibat dari penolakan tersebut, kiai Hasyim dan beberapa putra serta sahabatnya diringkus dalam penjara dan dipukuli oleh pihak Jepang. Kiai Hasyim memberikan fatwa haram dalam upacara tersebut, bahwa tidak seharusnya seorang Muslim menyembah selain Allah, selain itu juga tiada kewajiban untuk menyembah sesama manusia karena itu merupakan perbuatan menyekutukan Tuhan. ${ }^{36}$ Hal ini adalah perjuangan kiai Hasyim dan para ulama pesantren dalam menanamkan jiwa kebangsaan yang tangguh dan patriotik dalam mengusir penjajah dari NKRI.

\section{NU dan NKRI: Sumbangsih KH Hasyim Asy'ari untuk Indonesia}

Berbicara tentang kiai Hasyim berarti berbicara tentang NU. Telah diketahui bersama bahwa tujuan didirikannya NU bukan hanya sekedar sebagai penyelamat aset kultural-teologis masyarakat tradisional, melainkan juga untuk membebaskan bumi pertiwi dari proteksi kolonialisme Belanda dan Jepang. Dengan demikian, sudah menjadi keharusan sejarah untuk mendirikan ormas NU baik untuk bangsa Indonesia maupun umat Islam sendiri. Dalam perkembangannya, NU terbagi menjadi beberapa periode, yang setiap periodenya terdapat pergeseran paradigma keislaman sebagai hasil dari berbagai sentuhan dengan kondisi sosial, teologis, maupun dalam konstelasi politik. ${ }^{37}$

Sejak awal didirikannya NU pada tanggal 31 Januari 1926, para pemimpin NU segera mensosialisasikannya kepada masyarakat sebagai ormas yang berpaham Ahlussunnah walJama'ah. Selain itu, kiai NU mulai menjalankan berbagai program yang berkaitan dengan persoalan ekonomi, sosial-kemasyarakatan, pendidikan dan dakwah Islamiyah. Dalam bidang pendidikan, para kiai memperluas area pendidikan dan memperbanyak cabang, dua madrasah

\footnotetext{
${ }^{33}$ Madar F Mas'udi, dkk. Dinamika Kaum Santri: Menelusuri Jejak dan Pergolakan Internal NU, (Jakarta: CV. Rajawali, 1983), 38.

${ }^{34}$ Yusrianto, "Pemikiran Politik dan Perjuangan KH. M. Hasyim Asy'ari Melawan Kolonialisme", In Right: Jurnal Agama dan Hak Asasi Manusia, Vol. 3, No. 2, 2014, 269.

${ }^{35}$ Seikerei merupakan kewajiban memberikan penghormatan dengan cara membungkukkan badan ke arah Tokyo setiap pukul 07.00 sebagai simbol penghormatan kepada Kaisar Hirohito dan ketundukan pada Dewa Matahari, lihat, Ahmad Irawan, Penakluk Badai, Novel Biografi KH. Hasyim Asy'ari, (Yogyakarta: Klam Nusantara, 2016).

${ }^{36}$ Zuhairi Misrawi, Hadratus Syaikh Hasyim Asy'ari: Moderasi, Keutamaan, dan Kebangsaan, (Jakarta: Pustaka Kompas, 2010), 50.

${ }^{37}$ Miftahuddin, "Dari Pesantren Untuk Negeri,....310.
} 
yang didirikan oleh kiai Wahab Chasbullah yaitu Nahdlatul Wathan dan Tashwirul Afkar. NU juga menerbitkan berbagai brosur, buletin, dan majalah dengan tujuan untuk mempermudah masyarakat dalam mengakses ke-NU-an. Gerakan dibidang sosial-kemasyarakatan ditandai dengan memantapkan hubungan dengan warga NU. Para kiai menggelar pertemuan rutin setiap hari Jum'at, mulai tingkat pusat sampai ranting. Sementara di bidang ekonomi mulai didirikan koperasi serba ada dalam rangka memajukan perekonomian NU. Masa perintisan NU sampai tahun 1942 mengalami penambahan anggota dan ekspansi geografis yang semakin luas, dan setiap tahunnya selalu mengalami kenaikan. ${ }^{38}$

Setelah NU tersebar di berbagai pulau yang ada di Nusantara, program NU selanjutnya adalah menjalin komunikasi dan konsolidasi dengan pihak luar NU, seperti SI, Muhammadiyah dan Persis, juga dengan mereka yang mengaku sebagai kelompok nasionalis. Niat tulus NU untuk merajut kembali hubungan dengan sesama ormas Islam Modernis yang sempat mengalami kerenggangan, tanggal 18-21 September 1937, dua tokoh NU yaitu kiai Ahmad Dahlan dan kiai Wahab Chsbullah bersama kiai mas Mansur (Muhammadiyah) dan Wondoamiseno (PSII) mempelopori berdirinya Majelis Ulama A'la Indonesia (MIAI) yang dilaksanakan di pondok Pesantren Kebondalem, Surabaya, di kediaman kiai Ahmad Dahlan. ${ }^{39}$

Keberadaan MIAI tidak bisa dilepaskan dari peran kiai Hasyim Asy'ari, karena beliau telah menyerukan supaya umat Islam bersatu dalam menghadapi ancaman dari luar Islam. Seruan itulah yang kemudian ditindaklanjuti oleh kiai Achmad Dahlan dan kiai Wahab Chasbullah di mana keduanya menjadi inisiator MIAI. Setelah itu, MIAI menjadi persatuan beberapa ormas Islam yang berperan untuk memajukan Islam serta berfungsi sebagai kontrol efektif bagi pemerintahan. Bukan hanya itu, kemajuan MIAI mampu menembus mancanegara yang ketika itu dipimpin oleh putra kiai Hasyim, yaitu kiai Wahid Hasyim yang berkedudukan sebagai Dewan Pleno. Hal ini ditandai dengan pembentukan sejumlah badan otonom NU yang menangani permasalahan yang berkaitan dengan warga NU dan ke-NU-an. Seperti yang terjadi tahun 1938 yang berhasil membentuk Lembaga Ma'arif NU yang bertugas dalam masalah pendidikan. Selain itu, permasalahan perempuan juga tidak luput dari permasalahan yang menjadi bahasannya, kemudian diberi nama Nahdlotoel Oelama bagian Moeslimat (NOM) yang saat ini dikenal dengan sebutan Muslimat NU. ${ }^{40}$

Keberadaan NU juga ikut menentukan calon pemimpin nasional. Pada Muktamar NU ke-15 tahun 1940 di Surabaya, NU telah melakukan rapat rahasia yang hanya dihadiri 11 orang tokoh NU yang dipimpin oleh kiai Mahfud Siddiq. Hasil rapat tersebut memutuskan untuk memilih Ir. Soekarno sebagai pemimpin dan Drs. Mohammad Hatta sebagai wakil presidennya, kedua tokoh inilah yang dianggap sebagai figur yang tepat untuk memimpin Indonesia. Setelah Belanda pergi dari Indonesia, pada tahun 1942 Jepang datang untuk menjajah Indonesia. Di masa penjajahan Jepang inilah NU mengalami kesulitan hingga banyak tokoh NU yang dijebloskan ke penjara, seperti kiai Hasyim Asy'ari dan kiai Mahfud Siddiq yang dituduh telah menggalang kekuatan massa untuk melawan saudara tua. ${ }^{41}$

\footnotetext{
${ }^{38}$ Hartono Margono, KH. Hasyim Asy'ari dan Nahdlatul Ulama Jurnal Media Akademika, Vol. 26, No. 3, (Juli 2011), 345.

${ }^{39}$ Hartono Margono, KH. Hasyim Asy'ari dan Nahdlatul Ulama,......, 347.

${ }^{40}$ Hartono Margono, KH. Hasyim Asy'ari dan Nahdlatul Ulama,......, 349.

${ }^{41}$ Hartono Margono, KH. Hasyim Asy'ari dan Nahdlatul Ulama,......, 353.
} 
Perlakuan Jepang terhadap pemimpin NU tersebut megundang simpati dari warga NU. Mereka kemudian membentuk laskar jihad yang diberi nama Hizbullah dan Sabilillah yang dipimpin oleh kiai Wahid Wahab, kiai Saefuddin Zuhri, kiai Masjkur dan beberapa tokoh NU lainnya. Perjuangan tersebut akhirnya berbuah manis, tanggal 29 April 1945 dibentuklah BPUPKI (Dokuritsu Zyunbi Tyoosakai) yang beranggotakan 62 orang yang bertugas untuk menetapkan dasar Indonesia merdeka, kiai Hasyim juga ikut serta dalam merumuskan Dasar Negara. Tanggal 1 Juni 1945 Soekarno mengemukakan Pancasila, kemudian disusun hingga menjadi Piagam Jakarta pada 22 Juni 1945. Lalu tanggal 12 Agustus 1945 didirikan PPKI (Panitia Persiapan Kemerdekaan Indonesia) atau lebih spesifik lagi adalah "Panitia Sembilan" yang bertugas merumuskan dasar negara. KH . Wahid Hasyim yang merupakan putra pendiri NU (kiai Hasyim Asy’ari) merupakan salah satu anggota Panitia Sembilan yang bertugas merumuskan dasar negara. PPKI melakukan sidang pertamanya pada 18 Agustus 1945 setelah Ir. Soekarno dan Moh. Hatta memproklamasikan kemerdekaan Indonesia. ${ }^{42}$

Piagam Jakarta yang saat ini tertuang dalam Pembukaan UUD 1945, sesungguhnya telah mengalami beberapa perubahan yang cukup signifikan dalam ranah teologi negara Indonesia. Hal ini disebabkan oleh adanya tujuh kata yang menjadi kontroversi dan perdebatan di antara founding father, yaitu Ketuhanan yang Maha Esa dengan menjalankan syari'at Islam bagi para pemeluknya. Penghapusan tujuh kata tersebut memberikan dampak yang krusial bagi landasan ideologi bangsa. Seandainya tujuh kata tersebut masih termaktup dalam Piagam Jakarta maka konsekuensi yang harus dihadapi adalah dasar negara Indonesia hanya berdasar pada satu agama tertentu, padahal masyarakat Indonesia merupakan masyarakat yang plural, terdapat berbagai agama yang tersebar dalam berbagai pulau dan daerah. Penghapusan tujuh kata dalam Piagam Jakarta ini ditujukan sebagai bentuk toleransi umat Islam yang luar biasa dalam menghargai perbedaan dan kebhinekaan. ${ }^{43}$

Pendiri NU, yaitu kiai Hasyim Asy'ari lah yang melakukan proses berpikir dan berserah diri pada Allah sebelum akhirnya mengambil sikap terkait penghapusan tujuh kata dalam piagam Jakarta. Alasan dihapuskannya tujuh kata tersebut adalah demi persatuan dan kesatuan bangsa Indonesia. Akhirnya, pada sidang PPKI tanggal 18 Agustus 1945, tujuh kata setelah kata ketuhanan disepakati bersama untuk dihapus. Menurut Andree Feilard, NU memiliki andil yang begitu besar dalam penghapusan tujuh kata "Islam" dalam Piagam Jakarta. $^{44}$

\section{Penutup}

Hadratusy Syaikh Hasyim Asy'ari adalah pahlawan nasional, jasa dan perjuangannya untuk bangsa Indonesia tak dapat dielakkan lagi. Mulai dari bidang sosial keagamaan dan pendidikan, hingga bidang perpolitikan. Kiai Hasyim hidup ketika masyarakat Indonesia sedang gencarnya menghadapi permasalahan teologis dan perang melawan penjajahan. Permasalahan teologi dihadapi masyarakat ketika para pembaharu Islam mengkritisi segala apa yang dilakukan umat Muslim Indonesia, bahkan ada sebagian dari masyarakat mulai terkontaminasi oleh ajaran-ajaran pembaharu, hal ini yang kemudian menjadikan masyarakat terpecah. Kekacauan semakin menjadi ketika para penjajah datang ke Indonesia dan

\footnotetext{
${ }^{42}$ Muhammad Mustaqim, "Politik Kebangsaan Kaum Santri: Studi Atas Kiprah Politik Nahdlatul Ulama", Jurnal ADDIN, Vol. 9, No. 2, 2015, 342.

${ }^{43}$ Muhammad Mustaqim, "Politik Kebangsaan Kaum Santri..... 343.

${ }^{44}$ Andre Feillard, NU Vis a Vis Negara, (Yogyakarta: LKiS, 1999), 39.
} 
memanfaatkan keadaan masyarakat yang saling berseteru. Dalam mengadapi situasi tersebut, Kiai hasyim mendirikan pesantren untuk menguatkan akidah umat Muslim, di samping itu beliau juga mendirikan organisasi Nahdlatul Ulama (NU).

NU didirikan untuk mengatasi permasalahan sosial, agama, dan politik. Membicarakan kiai Hasyim berarti berbicara tentang NU. Jasa yang diberikan kiai Hasyim dan NU sangat besar untuk Indonesia. Terlihat dari adanya fatwa jihad yang dikeluarkan kiai Hasyim, bahwa setiap Muslim diwajibkan memerangi segala bentuk penjajahan, karena orang yang gugur dalam peperangan melawan penjajah dihukumi sebagai mati dalam keadaan syahid, dan Allah menjanjikan Surga untuknya. Jihad yang difatwakan kiai Hasyim tersebut mendapatkan respon positif dari masyarakat dan para pemuda NU, sehingga mereka akhirnya bersatu melawan para penjajah dan mengusirnya dari bumi pertiwi ini. Setelah Indonesia merdeka, para pendiri bangsa mulai menyusun dasar negara Pancasila dan mencantumkannya dalam Piagam Jakarta. Kiai Hasyim adalah orang yang paling berjasa dalam mempersatukan masyarakat Indonesia, terbukti dari jerih payah beliau dalam menghapuskan tujuh kata kontroversial dalam Piagam Jakarta. Kiai Hasyim selalu mengutamakan asas kemaslahatan dan kerukunan umat di atas segalanya, dari penghapusan tujuh kata dalam Piagam Jakarta tersebut menggambarkan bahwa kiai Hasyim adalah tokoh, ulama, dan guru bangsa yang sangat toleran.

\section{Daftar Rujukan}

Anam, Ahmad Khoirul, dkk. Ensiklopedia Nahdlatul Ulama: Sejarah, Tokoh, dan Khazanah Pesantren Jilid 2, Jakarta: Pustaka Kompas, 2014.

Asmani, Jamal Ma'mur, Pemikiran Kiai Hasyim Asy'ari: tentang Agama, Perempuan, dan Kemasyarakatan, Yogyakarta: Aswaja Pressindo, 2018.

Asy'ari, M. Hasyim, Ar-Risalat al-Jami'at al-Maqasid, Jombang: Pustaka Warisan Islam Tebuireng, tt.

Aziz, Muhammad, Ahmad Rofiq, and Abdul Ghofur. "Regulation on the Implementation of Halal Product Guarantee in Indonesia from the Perspective of the Statute Approach". ISLAMICA: Journal of Islamic Studies 14, no. 1 (September 1, 2019): 151-170. Accessed May 21 , 2020. http://islamica.uinsby.ac.id/index.php/islamica/article/view/577

Aziz, Muhammad; SHOLIKAH, Sholikah. The Method of Professional Zakat Law Istinbat Yusuf Al-Qardawi Perspective and Its Implications for the Development of Zakat Objects in Indonesia. ULUL ALBAB Journal of Islamic Studies, [Sl], v. 16, n. 1, p. 89 - 116, sep. 2015. ISSN 2442-5249. Available at: < http://ejournal.uinmalang.ac.id/index.php/ululalbab/article/view/3039 >. Date accessed: 13 dec. 2019. doi : http://dx.doi.org/10.18860/ua.v16i1.3039 .

Aziz, Muhammad. (2018). The Perspective of Maqashid Al-Sharia in the Implementation of Halal Product Guarantee in Indonesia after the enactment of Law Number 33 of 2014 concerning Halal Product Guarantee. Al Hikmah: Journal of Islamic Studies , 7 (2), 78-94. https://doi.org/10.36835/hjsk.v7i2.3284

Bush, Robin dan Greg Fealy, "The Political Decline of Traditional Ulama in Indonesia", Asian Journal of Social Science, Vol. 42, No. 5, 2014. https://doi.org/10.1163/15685314-04205004

Chotimah, Chusnul, "Aktualisasi Pemikiran KH. M. Hasyim Asy'ari tentang Kenegaraan dan Kebangsaan", Jurnal Inovatif, Vol. 3, No. 2, 2018.

Daman, Rozikin, Membidik NU: Dilema Percaturan Politik NU Pasca-Khittah, Yogyakarta: Gama Media, 2001. 
Fadli, Mohammad Rizal dan Hidayat, KH. Hasyim Asy'ari dan Resolusi Jihad dalam Usaha Mempertahankan Kemerdekaan Indonesia Tahun 1945, Lampung: Laduny Alifatama, 2018.

Feillard, Andre, NU Vis a Vis Negara, Yogyakarta: LKiS, 1999.

Irawan, Ahmad, Penakluk Badai, Novel Biografi KH. Hasyim Asy'ari, Yogyakarta: Klam Nusantara, 2016.

Khasanah dan Waskito, "Genealogi Pemikiran Pendidikan KH. Hasyim Asy’ari”, Analisa: Jurnal Studi Keislaman, 2019. http://doi.org/10.24042/ajsk.v19il.3397

Khuluq, Lathifatul, Fajar Kebangunan Ulama: Biografi KH. Hasyim Asy'ari, Yogyakarta: LkIS, 2000.

Khuluq, Latifatul, Hasyim Asy'ari: Religous Thought and Polirical Activities (1871-1947), Jakarta: Logos.

Margono, Hartono, KH. Hasyim Asy'ari dan Nahdlatul Ulama Jurnal Media Akademika, Vol. 26, No. 3, Juli 2011.

Mas'udi, Madar F, dkk. Dinamika Kaum Santri: Menelusuri Jejak dan Pergolakan Internal NU, Jakarta: CV. Rajawali, 1983.

Miftahuddin, "Dari Pesantren Untuk Negeri: Kiprah Kebangsaan KH. Hasyim Asy'ari”, Jurnal Islam Nusantara, Vol. 03, No. 02, 2019.

Misrawi, Zuhairi, Hadratussyaikh Hasyim Asy'ari: Moderasi, Keutamaan, dan Kebangsaan, Jakarta: Pustaka Kompas, 2010.

Mustaqim, Muhammad, "Politik Kebangsaan Kaum Santri: Studi Atas Kiprah Politik Nahdlatul Ulama", Jurnal ADDIN, Vol. 9, No. 2, 2015.

Ni'am, Syamsun, Wasiat Tarekat Hadratus Syaikh Hasyim Asy'ari, Jogjakarta: Ar-Ruzz Media, 2011.

Nizar, Muchamad Coirun, "Pemikiran KH. Hasyim Asy'ari tentang Persatuan", Endogami: Jurnal Ilmiah Kajian Antropologi, 2017. http://www.DOI:10.14710/endogami.1.1.63$\underline{74}$

Noer, Deliar, Gerakan Islam di Indonesia 1900-1942, Jakarta: LP3ES, 1996.

Ricklefs, Merle Calvin, Mengislamkan Jawa: Sejarah Islamisasi di Jawa dan Penentangnya dari 1930 sampai Sekarang, Jakarta: Serambi Ilmu Pustaka, 2012.

Sholikah, S. (2017). Relevansi Kompetensi Pendidik Menurut K.H. Hasyim Asy'ari Dengan UU Sisdiknas Tahun 2003. Al Hikmah: Jurnal Studi Keislaman, 7(1). https://doi.org/10.36835/hjsk.v7i1.3091.

Sholikah, S. 2015. Pendidikan Karakter Menurut K.H. Hasyim Asy'ari dalam Kitab Adâb al-'Âlim wa al-Muta'allim. Maraji: Jurnal Ilmu Keislaman. 2, 1 (Sep. 2015), 117-143. DOI:https://doi.org/10.36835/maraji.v2i1.40.

Sholikah, S. (2015). Pendidikan Karakter Menurut K.H. Hasyim Asy'ari dalam Kitab Adâb al-'Âlim wa al-Muta'allim. Maraji: Jurnal Ilmu Keislaman, 2(1), 117143. https://doi.org/10.36835/maraji.v2i1.40.

Tim Dosen Ma'had Aly Hasyim Asy'ari, Cahaya Purnama Kekasih Tuhan, terj. Nur alMubin fi Mahabbat as-Sayyid al-Mursalin, Tebuireng: Pustaka Tebuireng.

Tim Dosen Ma'had Aly Hasyim Asy'ari, Cahaya Penerang Jiwa, terj. Risalah Ahl-asSunnah wa al-Jama'ah, Tebuireng: Pustaka Tebuireng.

Yusrianto, "Pemikiran Politik dan Perjuangan KH. M. Hasyim Asy'ari Melawan Kolonialisme", In Right: Jurnal Agama dan Hak Asasi Manusia, Vol. 3, No. 2, 2014.

Zuhri, Achmad Muhibbin, Pemikiran KH. M. Hasyim Asy'ari: tentang Ahl as-Sunnah wa alJama'ah, Surabaya: Khalista, 2010.

Zuhri, Saifuddin, Berangkat dari Pesantren, Yogyakarta: LKiS, 2013. 